\title{
Historical perspectives of The American Association for Thoracic Surgery: Hartzell V. Schaff, MD
}

\author{
John R. Spratt, MD, MA, and Sara J. Shumway, MD
}

\author{
From the Department of Surgery, University of Minnesota Medical School, Minneapolis, Minn. \\ Disclosures: Authors have nothing to disclose with regard to commercial support. \\ Received for publication Feb 12, 2017; accepted for publication Feb 28, 2017; available ahead of print March 31, \\ 2017. \\ Address for reprints: Sara J. Shumway, MD, Division of Cardiothoracic Surgery, Department of Surgery, Univer- \\ sity of Minnesota Medical School, 420 Delaware St, SE, Mayo Mail Code 195, Minneapolis, MN 55455 \\ (E-mail: shumw001@umn.edu). \\ J Thorac Cardiovasc Surg 2017;154:1-6 \\ $0022-5223 / \$ 36.00$ \\ Copyright $(2017$ by The American Association for Thoracic Surgery \\ http://dx.doi.org/10.1016/j.jtcvs.2017.02.043
}

\section{EARLY LIFE AND TRAINING}

Hartzell Vernon Schaff, MD, the 93rd president of The American Association for Thoracic Surgery (AATS), was born in Holdenville, Okla, the middle of 3 children born to Ruth Schaff and Hartzell V. Schaff, Sr, a general surgeon decorated for his service in Europe during World War II. While in high school, the younger Schaff distinguished himself both in the classroom and on the athletic field before starting his undergraduate work at the University of Oklahoma in Norman (1966-1969). He would stay at the University of Oklahoma for medical school (1969-1973), where he became interested in thoracic surgery under the mentorship of G. Rainey Williams, MD. ${ }^{1}$ During his final year of medical school, he was the President of both his medical school class and the Oklahoma chapter of the Alpha Omega Alpha honor society and would go onto be valedictorian, earning the L.G. Mormon award. He met his wife, Voni, during his pediatrics rotation; they married following his graduation.

With the encouragement of Williams and other early mentors, including Lazar Greenfield, MD, and Ron Elkins, MD, Dr Schaff secured a position at Johns Hopkins Hospital for surgical training and he and Voni moved to Baltimore, Md. ${ }^{1}$ He completed the entirety of his training in the then-steeply pyramidal program at Johns Hopkins, including internship (1973-1974) and residency (19741975, 1976-1978) in general surgery and clinical fellowship in cardiac and thoracic surgery (1978-1980). The Schaffs welcomed 4 children during training. ${ }^{2}$

While at Johns Hopkins, Dr Schaff also completed a research fellowship in the Cardiovascular Surgical Research Laboratory (1975-1976) under Vincent Gott, MD, then the chief of cardiac surgery at Johns Hopkins, during which time he studied myocardial protection. An important component of his work during this period was demonstration of the relationship between myocardial injury and diastolic function, showing that edematous myocardium resulting from ischemia-reperfusion leads to

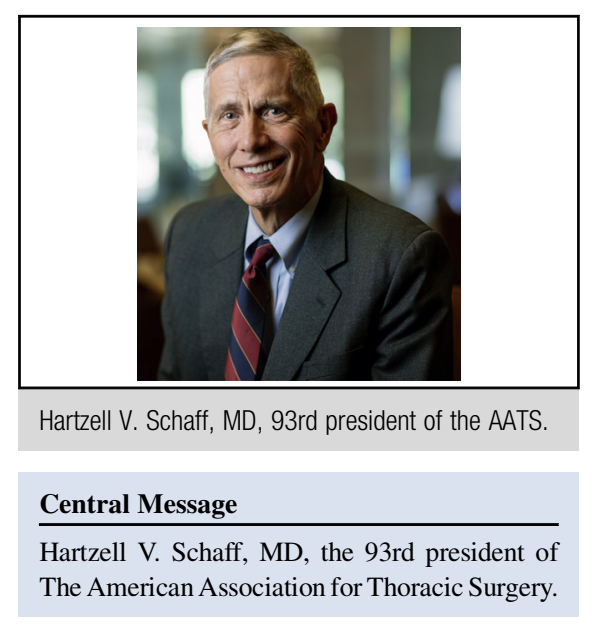

decreased intraventricular volume and elevated enddiastolic pressure. ${ }^{3,4}$ He earned the George D. Zuidema Resident Research Award in 1980 for his efforts and he would later partially attribute his success in developing apical myectomy to insights he gained while performing these experiments. ${ }^{1}$ Of note, a close collaborator in the lab was Timothy Gardner, MD, the 82 nd president of the AATS. The pair coauthored numerous articles on myocardial ischemia-reperfusion and postoperative autotransfusion, among other topics, during this time.,

Quiet, dedicated, and hard-working, Dr Schaff developed a reputation for academic and clinical excellence early in his time at Johns Hopkins that has only grown in the years since. On a typical weekend morning when many arrived to the hospital still half asleep, it was common to find him hard at work on a manuscript, having arrived hours earlier. For years after he departed Baltimore, to have done something "the way Hartzell might have done it" was considered highest praise in the hallways at Hopkins (D.E. Cameron, oral communication, December 2016).

\section{CAREER}

\section{The Mayo Clinic}

At the conclusion of his training, Dr Schaff was recruited the to the Mayo Clinic in Rochester, Minn, by James Pluth, $\mathrm{MD}$, who at the time was the chief of cardiovascular surgery. Among his closest colleagues during these early years as an attending surgeon were Dwight McGoon, MD, the 64th president of the AATS; Gordon Danielson, MD; and 
Francisco Puga, MD. He was promoted to chair of the Division of Cardiovascular Surgery in 2001 (Figure 1).

\section{Department Leadership}

As division chief, Dr Schaff demonstrated a leadership style that was fair, data-driven, and outwardly focused. When dealing with administrative issues or disputes, he worked to collect and analyze salient facts on their own merit and refused to succumb to groupthink or prevailing opinions without first reaching his own independent conclusions. He worked to promote the priorities of the division over himself and also to advance the careers of young collaborating surgeons both within and outside his own institution and continues to do so today, in part by leading from the front, and maintaining a high level of clinical and academic productivity ${ }^{1}$ (J.A. Dearani and R.C. Daly, oral communication, December 2016).

Among his lasting contributions to the division is a continual push for involvement in national societies, including the AATS and Society of Thoracic Surgeons, and on editorial boards of relevant journals. He believes this provides an opportunity to groom early and midcareer surgeons to become leaders in the field and for senior faculty to remain engaged in the specialty as a whole and to maintain opportunities for collaboration and access to new techniques. Another major contribution was his early and persistent advocacy for the creation of an independent department of cardiovascular surgery at Mayo. He believes strongly that cardiovascular surgery, because of its unique

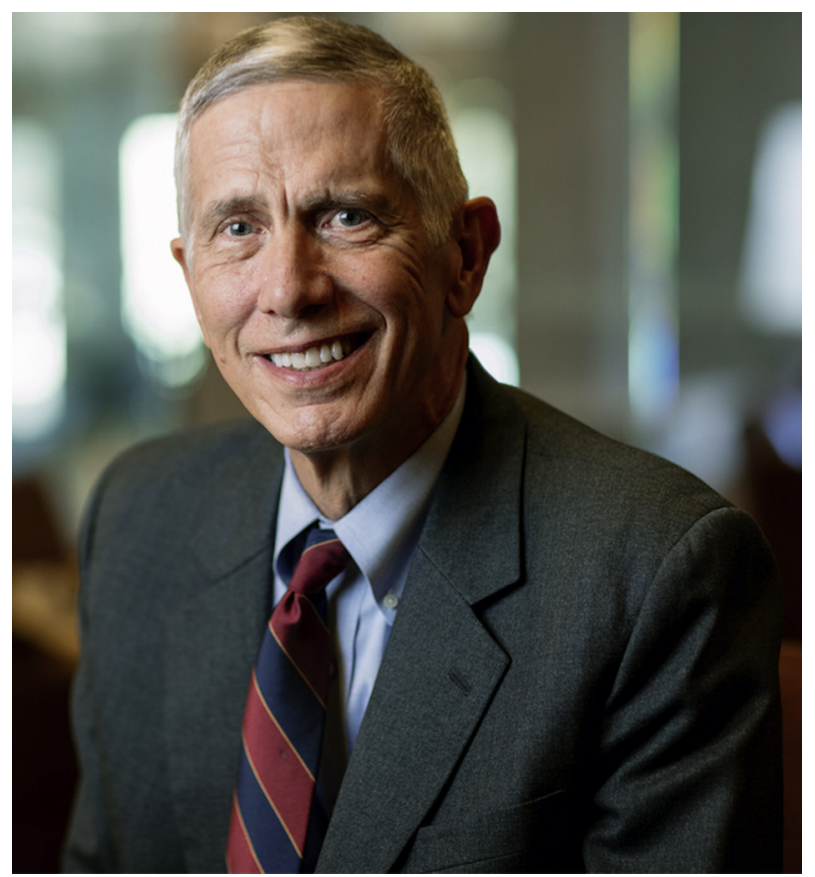

FIGURE 1. Hartzell V. Schaff, MD, 93rd president of The American Association for Thoracic Surgery. needs, language, technology, and culture, should have its own voice (J.A. Dearani, oral communication, December 2016). Although he stepped down as chief in 2011, this vision would be realized and implemented fully in 2017 . He remains an active member of the clinical staff at Mayo.

\section{ACADEMIC ACCOMPLISHMENTS}

Through a combination of towering intellect and outstanding time-management skills, Dr Schaff is considered by his peers to be an academic dynamo (J.A. Dearani and R.C. Daly, oral communication, December 2016). He has written or coauthored approximately 800 scientific articles, 400 abstracts, and 100 textbook chapters on nearly every topic in adult cardiovascular surgery, including large experiences with a number of uncommon but important topics, including the management of the fibrotic and/or irradiated mediastinum, pericardial disease, aortic dissection in pregnancy, and the use of left ventricular (LV) apical-aortic conduits for aortic stenosis not amenable to traditional approaches. $^{7-11}$

Among the most widely cited of his major publications is the first major report of an association between the combination of the weight-loss drugs fenfluramine and phentermine and left-sided valvular regurgitation. ${ }^{12}$ This drug combination, known in the 1990s as Fen-Phen, was withdrawn from the market at the request of the US Food and Drug Administration shortly after the 1997 publication of this report and would go on to be the subject of several large legal settlements. ${ }^{13}$ Despite these accomplishments, Dr Schaff is arguably better known for his substantial contributions to a number of more mainstream areas of adult cardiovascular surgery.

\section{Hypertrophic Cardiomyopathy}

Although the first operations for hypertrophic cardiomyopathy (HCM) were developed in the 1960s, Dr Schaff and his partners at Mayo have become clinical and thought leaders in the field during the years since. ${ }^{14}$ Examples of this include reports of large series of transaortic septal myectomy for hypertrophic obstructive cardiomyopathy, longterm follow-up of LV remodeling after surgery for HCM, and the interplay between HCM and mitral valve disease, among others. ${ }^{15-17}$ More recent efforts have focused on the optimal role of catheter-based interventions for HCM. ${ }^{18}$

Dr Schaff first became attuned to the issues presented by HCM as a resident in the research lab at Johns Hopkins, when he observed diastolic dysfunction in stiff and edematous postischemic myocardium (mentioned above). He would bring this perspective to the bedside later in his career with the development of apical myectomy for the management of apical HCM. ${ }^{1}$ First performed in 1993, apical myectomy consists of an apical ventriculotomy and careful resection of hypertrophic segments of the apical septum, anterior LV wall, and selective shaving of the 
papillary muscles, aimed at lowering end-diastolic pressure by augmenting LV volume. ${ }^{19}$ Apical HCM can be disabling in some patients and, before the development of this procedure, the only beneficial long-term therapy was heart transplantation. The use of apical myectomy has improved the functional status of many patients with apical HCM and, at least anecdotally, has either delayed or eliminated the need for transplantation in some patients (J. A. Dearani, oral communication, December 2016).

\section{Mitral Valve Disease and Atrial Fibrillation}

Investigation of the treatment of mitral valve (MV) disease has been a staple of Dr Schaff's academic career. His early work in this area included large series investigating reoperative valvular disease, multivalvular replacement, and mechanical sequelae of acute myocardial infarction. ${ }^{20-22}$ $\mathrm{He}$ would go on to become an early proponent of MV repair and played a significant role in the development and propagation of the triangular leaflet resection technique. ${ }^{23}$ He was also instrumental in expanding the indications for MV surgery to include diagnoses such as asymptomatic mitral regurgitation. ${ }^{24}$ An early adopter of the Cox-Maze procedure for atrial fibrillation at the time of MV surgery, he and his colleagues at Mayo have reported a large experience with the procedure ${ }^{25}$ Despite the widespread adoption of energy devices for left atrial ablation, Dr Schaff is said to be among the few practicing surgeons to still prefer the traditional cut-and-sew technique for the Cox-Maze procedure and continues to enjoy excellent outcomes with its use (K. Zehr, oral communication, December 2016).

\section{Adult Congenital Heart Disease}

Dr Schaff developed an early interest in the surgical management of adult congenital heart disease and has made significant contributions in this area. Among these is an extensive reported experience with caval division techniques for repair of anomalous pulmonary venous return and the use of extra-anatomic ascending-to-descending aortic bypass using a Dacron conduit through the posterior pericardium for primary or recurrent aortic coarctation, which is often paired with valvular or other interventions. ${ }^{26-29}$ Concordant with his interest in atrial fibrillation surgery, the use of right-sided Maze procedures and tricuspid valve repair for atrial tachyarrhythmia, heart failure, and/or pulmonary hypertension in adults with congenital heart disease are other areas of his expertise. ${ }^{30,31}$

\section{CLINICAL EXCELLENCE Patient Care}

Dr Schaff is a fastidious and skilled clinician with a direct interpersonal style and a meticulous approach to patient care who considers no detail to be too minor to be worthy of his attention (Figure 2). He has a reputation for being totally informed of all details of the status of his patients at all times, no doubt facilitated by the computer terminal in his home displaying the bedside monitoring of his ICU patients. This level of constant engagement in the care of his patients has earned him the respect and admiration of surgical and nonsurgical colleagues alike (J.A. Dearani, oral communication, December 2016). Beyond the minutiae of postoperative recovery, Dr Schaff has an established reputation of demonstrating clear thinking in the face of complex clinical problems and for developing safe and appropriate solutions before, during, and after surgery, leading referring physicians to involve him frequently in the care of challenging and high-profile patients (R.C. Daly, oral communication, December 2016).

\section{Technical Expertise}

Many of Dr Schaff's current and former colleagues were interviewed for this article and each went out of his way to praise Dr Schaff's operative skills, describing him as an "exceedingly gifted surgeon," and a "pure genius intuitive surgeon." One even went so far as to compare his rare and enviable technical prowess to the considerable shooting skills of professional basketball star Stephen Curry (D.E. Cameron, J.A. Dearani, R.C. Daly, D.D. Glower, and T. Gardner, oral communication, April and December 2016). Although he demonstrated technical excellence from early

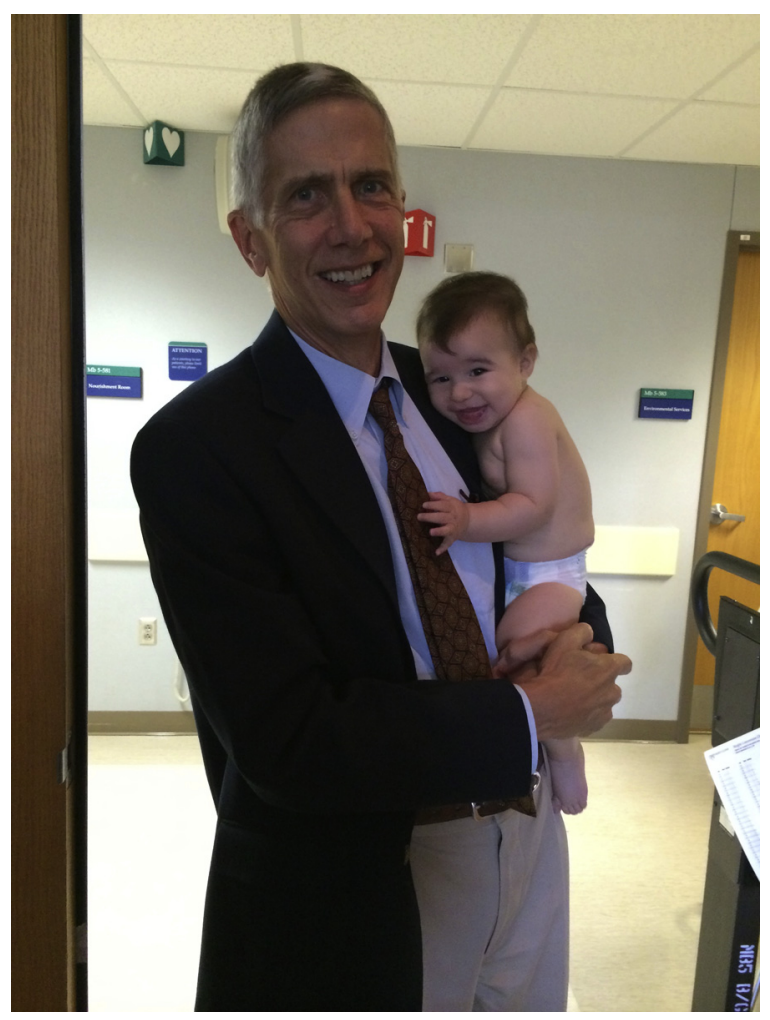

FIGURE 2. Hartzell V. Schaff, MD, on rounds assisted by the infant son of a patient. 


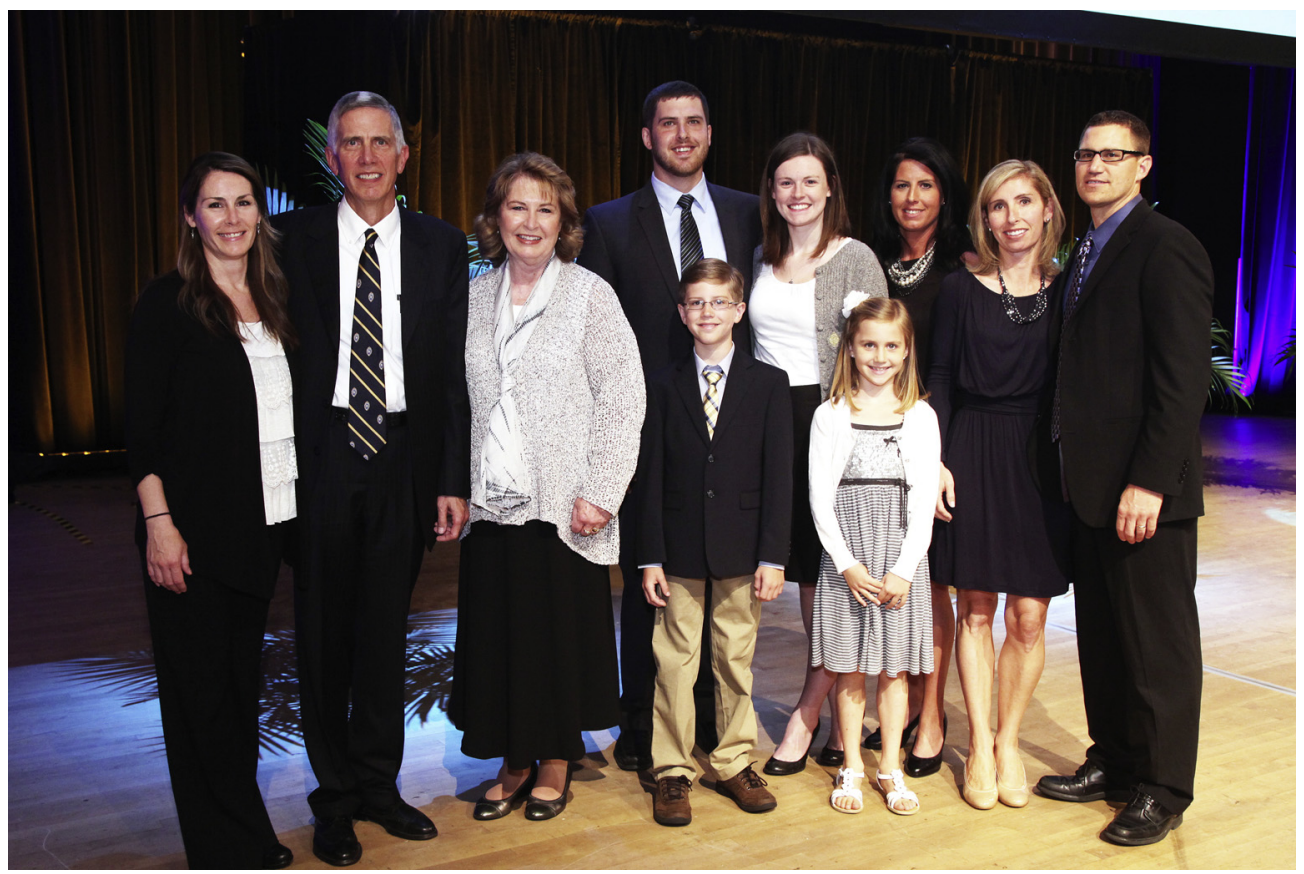

FIGURE 3. Hartzell V. Schaff, MD, with family following his presidential address at the 2013 Annual Meeting of The American Association for Thoracic Surgery, May 7, 2013, in Minneapolis, Minn.

in his training, his vast accumulated experience over his career has allowed him to streamline the conduct of even complex operations to their most essential steps and to perform them with great efficiency and economy of motion, leading to extremely short aortic crossclamp and cardiopulmonary bypass times and superior patient outcomes. Similar to when he was at John Hopkins, the question, "How does Hartzell do this?" is commonly heard at Mayo (K. Zehr, oral communication, December 2016). As a colleague described, "When input is needed regarding a difficult case, his advice is the most [valuable] since it will come directly from his vast surgical experience. He tells you precisely what you need to know and alerts you to the potential pitfalls...it's the kind of advice that won't be in a textbook or journal article, but only appreciated by someone who's been there" (J.A. Dearani, oral communication, December 2016).

\section{EXTRAMURAL LEADERSHIP AND SERVICE National Committee Service and International Outreach}

Dr Schaff has been an active member of national societies within and outside of cardiovascular surgery for the bulk of his career. A member of the American Heart Association since 1983, he has served on multiple American Heart Association committees, including the Council on Cardiovascular Surgery and Anesthesia, the Council on Circulation, and the Council on Basic Cardiovascular Sciences. He has been a Fellow of the American College of Cardiology since
1983 and has served on several American College of Cardiology committees. He is an active member of the Society of Thoracic Surgeons and has participated in the development of the Self-Education Self-Assessment in Thoracic Surgery program, along with multiple committees and workforces. Finally, he has been a member of the prestigious American Surgical Association since 1999.

$\mathrm{He}$ is also an active participant in multiple longitudinal multicenter clinical outcomes studies, including the Bypass Angioplasty Revascularization Investigation, and was a participant in the follow-up reports from the Coronary Artery Surgery Study. ${ }^{32,33} \mathrm{He}$ is a routine participant in the construction of national guidelines, most recently relating to percutaneous coronary intervention and imaging in pericardial disease. ${ }^{34,35}$

In addition to his domestic committee service, Dr Schaff has traveled extensively to share his wisdom and experience. He has lectured on every continent except Antarctica, including such far-away locations as South Africa, Croatia, Pakistan, Australia, Chile, Japan, and Israel, where he has served multiple times as a visiting professor at the Sheba Medical Center in Tel Aviv.

\section{Editorial Service}

As would be expected from an investigator with a curriculum vitae as long as Dr Schaff's, he has an extensive record of editorial service to journals focusing on cardiac disease. These include Circulation (2000-2007), Journal of Cardiac Surgery (1999-present), and European Heart Journal 


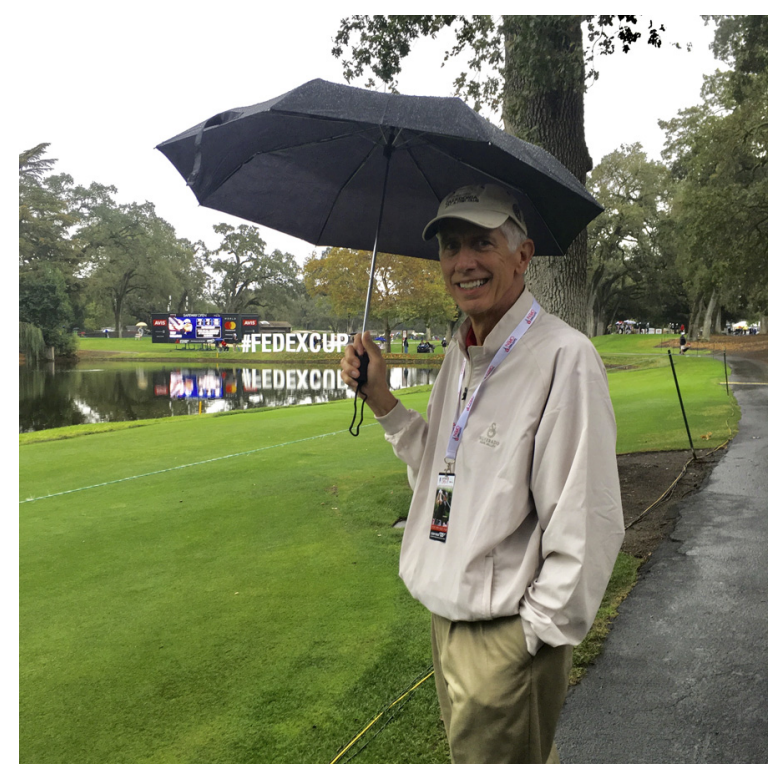

FIGURE 4. Hartzell V. Schaff, MD, braving the elements at the Safeway Open in Napa, Calif.

(2009-2011). He has also served as an ad hoc reviewer for Chest, Annals of Thoracic Surgery, Journal of Surgical Research, and New England Journal of Medicine.

Dr Schaff has had a long relationship with the The Journal of Thoracic and Cardiovascular Surgery. He has twice served as a member of the Editorial Board (1987-1992 and 1998-2003). He has served as a reviewer since 1987 and as a distinguished reviewer since 2005 . He currently serves as associate editor for acquired cardiac disease.

\section{AATS Leadership}

A member since 1987, Dr Schaff has served the AATS in many capacities. His first committee assignment was to the Graduate Education in Thoracic Surgery Committee (19992000). He would later serve on the Committee on New Technology Assessment (2002-2005), the Publications Committee (2011-2012), Abstract Committee (20122013), Academy Committee (2012-2013), and Leadership Academy Board (2012-2016). He was a member of the Program Committee from 2000-2013 and later served as the Association's President-elect (2011-2012) and President (2012-2013). Notable among his accomplishments during this time was the development of the AATS summer internship program for medical students, which was based on a summer research fellowship Dr Schaff completed in 1969 at the MD Anderson Hospital and Tumor Institute (now the MD Anderson Cancer Center) in Houston, Tex. ${ }^{2}$

\section{Presidential Address}

In his presidential address, "Leadership and Scholarship in Thoracic Surgery," Dr Schaff detailed the importance of these 2 values not only for individual surgical leaders and investigators, but also to the specialty writ large. $\mathrm{He}$ cautioned against allowing management, the operational processes of maintaining a division or department, from interfering with leadership, a concerted effort to motivate and support colleagues through a shared system of values, expertise, vision, and selflessness. He further emphasized the importance of inspiring others to succeed by acting intentionally as a role model. ${ }^{1}$

Regarding scholarship, he discussed the ongoing importance of resident research, not only as a means of career advancement but also as a way to gain expertise in a particular area and to develop a more nuanced relationship with the literature through writing, and potentially reviewing, articles. He went on to detail the process by which his early work observing diastolic dysfunction in injured myocardium granted him the insight to later develop apical myectomy, detailed above. He closed by stressing the ongoing importance of trainees and established investigators alike moving between bench and bedside to promote further advances. ${ }^{1}$

\section{FAMILY (AND GOLF)}

Dr Schaff has an active family life that includes annual vacations to Pawley's Island, SC. He and Voni have 4 children: Matt, a resident in urology at Temple University; Brynn, who lives with her family Rochester, Minn; Leslie, who works for a philanthropic arm of a large health care organization in the Twin Cities; and Sarah, who works with horses on a ranch in South Dakota. He also has 5 grandchildren: Dylan, Graham, Owen, Julia, and Veronica (Figure 3).

A profile such as this would not be complete without discussing an activity that Dr Schaff is said to approach with nearly the same level of seriousness as he does cardiac surgery: Golf (Figure 4). He is a fanatical and lifelong player and fan and visits the links or the driving range almost daily. However, he undoubtedly sometimes seeks refuge from the harsh Minnesota winters at the indoor golf center-complete with video camera for swing analysis-he has set up in his home (J.A. Dearani, oral communication, December 2016). He has been known to sneak in a round by himself after presentations at favorably located meetings.

In addition to these solo outings, he also plays regularly with friends and AATS colleagues. Notable among these is a 2015 round at Augusta National Golf Club, where Dr Schaff played as a guest of Wayne Isom, MD, and Len Girardi, MD, alongside the late Lawrence H. Cohn, MD, the 79th president of AATS, and Joseph Coselli, MD, the 96th president of the AATS, among others. Dr Girardi would later report, "[Dr Schaff] enjoyed himself immensely and played quite well... very thoughtful on the tee, appropriately aggressive on his approach shots, and very respectful of the treacherous Augusta greens" (L.N. Girardi, written communication, January 30, 2017). Other prominent playmates have included John Calhoon, 
MD; Storm Floten, MD; Fred Crawford, MD, the 83rd president of the AATS; and the late Denton Cooley, MD.

The authors thank Duke Cameron, MD, Richard Daly, MD, Joseph Dearani, MD, Timothy Gardner, MD, Donald Glower, MD, Len Girardi, MD, Wayne Isom, MD, Hartzell Schaff, MD, and Kenton Zehr, MD, for providing assistance with the manuscript.

\section{References}

1. Schaff HV. Leadership and scholarship in thoracic surgery. Presented at American Association for Thoracic Surgery Annual Meeting, May 2013, Minneapolis, MN.

2. Sugarbaker DJ. Introduction to presidential address. Presentated at American Association for Thoracic Surgery Annual Meeting, May 2013, Minneapolis, MN.

3. Schaff HV, Dombroff R, Flaherty JT, Bulkley BH, Hutchins GM, Goldman RA, et al. Effect of potassium cardioplegia on myocardial ischemia and post arrest ventricular function. Circulation. 1978;58:240-9.

4. Schaff HV, Gott VL, Goldman RA, Frederiksen JW, Flaherty JT. Mechanism of elevated left ventricular end-diastolic pressure after ischemic arrest and reperfusion. Am J Physiol. 1981;240:H300-7.

5. Schaff HV, Bixler TJ, Flaherty JT, Brawley RK, Donahoo JS, Goldman RA, et al. Identification of persistent myocardial ischemia in patients developing left ventricular dysfunction following aortic valve replacement. Surgery. 1979;86:70-7.

6. Schaff HV, Hauer J, Gardner TJ, Donahoo JS, Watkins L Jr, Gott VL, et al Routine use of autotransfusion following cardiac surgery: experience in 700 patients. Ann Thorac Surg. 1979;27:493-9.

7. Brown ML, Cedeño AR, Edell ES, Hagler DJ, Schaff HV. Operative strategies for pulmonary artery occlusion secondary to mediastinal fibrosis. Ann Thorac Surg. 2009;88:233-7.

8. Ling LH, Oh JK, Schaff HV, Danielson GK, Mahoney DW, Seward JB, et al. Constrictive pericarditis in the modern era: evolving clinical spectrum and impact on outcome after pericardiectomy. Circulation. 1999;100:1380-6.

9. Crestanello JA, Zehr KJ, Daly RC, Orszulak TA, Schaff HV. Is there a role for the left ventricle apical-aortic conduit for acquired aortic stenosis? J Heart Valve Dis. 2004; 13:57-62.

10. Handa N, McGregor CG, Danielson GK, Daly RC, Dearani JA, Mullany CJ, et al. Valvular heart operation in patients with previous mediastinal radiation therapy. Ann Thorac Surg. 2001;71:1880-4.

11. Immer FF, Bansi AG, Immer-Bansi AS, McDougall J, Zehr K, Schaff HV, et al Aortic dissection in pregnancy: analysis of risk factors and outcome. Ann Thorac Surg. 2003;76:309-14.

12. Connolly HM, Crary JL, McGoon MD, Hensrud DD, Edwards BS, Edwards WD, et al. Valvular heart disease associated with fenfluramine-phentermine. $N$ Engl J Med. 1997;337:581-8.

13. Centers for Disease Control and Prevention. Cardiac valvulopathy associated with exposure to fenfluramine or dexfenfluramine: U.S. Department of Health and Human Services interim public health recommendations, November 1997. MMWR Morb Mortal Wkly Rep. 1997;46:1061-6.

14. Maron BJ, Dearani JA, Ommen SR, Maron MS, Schaff HV, Gersh BJ, et al. The case for surgery in obstructive hypertrophic cardiomyopathy. J Am Coll Cardiol. 2004; $44: 2044-53$.

15. Mohr R, Schaff HV, Danielson GK, Puga FJ, Pluth JR, Tajik AJ. The outcome of surgical treatment of hypertrophic obstructive cardiomyopathy. Experience over 15 years. J Thorac Cardiovasc Surg. 1989;97:666-74.

16. Wan CKN, Dearani JA, Sundt TM, Ommen SR, Schaff HV. what is the best surgical treatment for obstructive hypertrophic cardiomyopathy and degenerative mitral regurgitation? Ann Thorac Surg. 2009;88:727-32.
17. Deb SJ, Schaff HV, Dearani JA, Nishimura RA, Ommen SR. Septal myectomy results in regression of left ventricular hypertrophy in patients with hypertrophic obstructive cardiomyopathy. Ann Thorac Surg. 2004;78:2118-22.

18. Quintana E, Sabate-Rotes A, Maleszewski JJ, Ommen SR, Nishimura RA, Dearani JA, et al. Septal myectomy after failed alcohol ablation: does previous percutaneous intervention compromise outcomes of myectomy? J Thorac Cardiovasc Surg. 2015;150:159-67.e1.

19. Schaff HV, Brown ML, Dearani JA, Abel MD, Ommen SR, Sorajja P, et al. Apical myectomy: a new surgical technique for management of severely symptomatic patients with apical hypertrophic cardiomyopathy. J Thorac Cardiovasc Surg. 2010;139:634-40.

20. Orszulak TA, Schaff HV, Danielson GK, Pluth JR, Puga FJ, Piehler JM. Results of reoperation for periprosthetic leakage. Ann Thorac Surg. 1983;35:584-9.

21. Gersh BJ, Schaff HV, Vatterott PJ, Danielson GK, Orszulak TA, Piehler JM, et al. Results of triple valve replacement in 91 patients: perioperative mortality and long-term follow-up. Circulation. 1985;72:130-7.

22. Nishimura RA, Schaff HV, Gersh BJ, Holmes DR, Tajik AJ. Early repair of mechanical complications after acute myocardial infarction. JAMA. 1986;256:47-50.

23. Suri RM, Burkhart HM, Schaff HV. A novel method of leaflet reconstruction after triangular resection for posterior mitral valve prolapse. Ann Thorac Surg. 2010; 89:e53-6.

24. Enriquez-Sarano M, Avierinos J-F, Messika-Zeitoun D, Detaint D, Capps M, Nkomo V, et al. Quantitative determinants of the outcome of asymptomatic mitral regurgitation. N Engl J Med. 2005;352:875-83.

25. Stulak JM, Sundt TM, Dearani JA, Daly RC, Orsulak TA, Schaff HV. Ten-year experience with the cox-maze procedure for atrial fibrillation: how do we define success? Ann Thorac Surg. 2007;83:1319-24.

26. Connolly HM, Schaff HV, Izhar U, Dearani JA, Warnes CA, Orszulak TA. Posterior pericardial ascending-to-descending aortic bypass. Circulation. 2001; 104(Suppl 1):I133-7.

27. Brown ML, Burkhart HM, Connolly HM, Dearani JA, Hagler DJ, Schaff HV. Late outcomes of reintervention on the descending aorta after repair of aortic coarctation. Circulation. 2010;122(Suppl 1):S81-4.

28. McKellar SH, Schaff HV, Dearani JA, Daly RC, Mullany CJ, Orszulak TA, et al. Intermediate-term results of ascending-descending posterior pericardial bypass of complex aortic coarctation. J Thorac Cardiovasc Surg. 2007;133:1504-9.

29. Said SM, Burkhart HM, Dearani JA, Eidem B, Stensrud P, Phillips SD, et al. Outcome of caval division techniques for partial anomalous pulmonary venous connections to the superior vena cava. Ann Thorac Surg. 2011;92:980-5.

30. Stulak JM, Dearani JA, Puga FJ, Zehr KJ, Schaff HV, Danielson GK. Right-sided maze procedure for atrial tachyarrhythmias in congenital heart disease. Ann Thorac Surg. 2006;81:1780-5.

31. Said SM, Dearani JA, Burkhart HM, Connolly HM, Eidem B, Stensrud PE, et al. Management of tricuspid regurgitation in congenital heart disease: Is survival better with valve repair? J Thorac Cardiovasc Surg. 2014;147:412-9.

32. Schaff HV, Gersh BJ, Fisher LD, Frye RL, Mock MB, Ryan TJ, et al. Detrimental effect of perioperative myocardial infarction on late survival after coronary artery bypass. Report from the Coronary Artery Surgery Study_CASS. J Thorac Cardiovasc Surg. 1984;88:972-81.

33. Singh A, Schaff HV, Mori Brooks M, Hlatky MA, Wisniewski SR, Frye RL, et al. On-pump versus off-pump coronary artery bypass graft surgery among patients with type 2 diabetes in the Bypass Angioplasty Revascularization Investigation 2 Diabetes trial. Eur J Cardiothorac Surg. 2016;49:406-16.

34. Klein AL, Abbara S, Agler DA, Appleton CP, Asher CR, Hoit B, et al. American Society of Echocardiography clinical recommendations for multimodality cardiovascular imaging of patients with pericardial disease. J Am Soc Echocardiogr. 2013;26:965-1012.e15.

35. King SB, Smith SC, Hirshfeld JW, Jacobs AK, Morrison DA, Williams DO, et al. 2007 focused update of the ACC/AHA/SCAI 2005 guideline update for percutaneous coronary intervention. J Am Coll Cardiol. 2008;51:172-209. 